\title{
Trump's foreign policy and NATO: Exit and voice
}

\author{
James Sperling ${ }^{1}$ and Mark Webber ${ }^{2 *}$ \\ ${ }^{1}$ Department of Political Science, University of Akron, Ohio and ${ }^{2}$ School of Government and Society, University of \\ Birmingham, UK \\ ${ }^{\star}$ Corresponding author. Email: m.a.webber.1@bham.ac.uk
}

(Received 24 January 2018; revised 20 January 2019; accepted 18 February 2019)

\begin{abstract}
Donald Trump assumed office in January 2017, committed to revamping US foreign policy and putting 'America First'. The clear implication was that long-held international commitments would be sidelined where, in Trump's view, the American interest was not being served. NATO, in the crosshairs of this approach, has managed to ride out much of the criticism Trump has levelled against it. Written off as 'obsolete' by the American president, it has fared better in the Trump era than many commentators had predicted. NATO exemplifies a tendency in US foreign policy, which pre-dates Trump, where open criticism stops short of abandonment. This pattern has continued since 2017 and indicates a preference for voice over exit. As such, it suggests that Trump's foreign policy is not always as illogical as many have assumed. Logic is borne of institutional context: Trump has chosen to articulate voice where institutionalisation makes exit unviable. Institutional resilience in general and NATO's case specifically has a wider relevance, both for transatlantic relations and international order.
\end{abstract}

Keywords: Trump; NATO; Voice; Exit

\section{Introduction}

The Trump presidency has been widely regarded as presaging the end of liberal international order even if this is an order from which the US has long benefited. That contradiction might be seen to follow predictably from a chaotic government and a capricious and intellectually shallow president. Yet is some other logic at work here? Is there actually purpose to Trump's foreign policy? During the presidential election campaign, Trump declared he would 'shake the rust off America's foreign policy' and break with the bipartisan consensus on America's role in the world. ${ }^{1}$ Yet once elected, his administration maintained many of America's long-held commitments, including those that had been (and continued to be) the target of Trump's criticism. Trump's is a foreign policy characterised by many as transactional, one where costs and benefits matter more than ideas and norms. ${ }^{2}$ The interplay of commitment and criticism in this context, we argue, is an expression of voice because in institutionalised settings exit is rarely a viable option. We pursue this claim by reference to institutionalist lines of enquiry, in turn informed by Albert Hirschman's classic formulation of exit, voice, and loyalty. Our evidence is drawn from an overview of American policy towards NATO. In keeping with the theme of the journal's Forum, much of the analysis is premised on an assumption that NATO is characterised by an asymmetry of power that favours the US. To understand the relevance of our argument - what we are

\footnotetext{
${ }^{1}$ Demetri Sevestopulo, 'Trump pledges to "shake the rust" off US foreign policy', Financial Times (27 April 2016), available at: $\{$ https://www.ft.com/content/121cfa22-0ca7-11e6-9cd4-2be898308be3\}.

${ }^{2}$ Doug Stokes, 'Trump, American hegemony and the future of the liberal international order', International Affairs, 94:1 (2018), p. 137.
} 
seeking to explain and why it is important - we first explore a little further the implications of the Trump administration for international order.

\section{The Trump challenge: Order and institutions}

Trump's signature speeches on foreign policy have put 'America First', so elevating nationalism above global governance. ${ }^{3}$ The idea of the US as a benign hegemon dedicated to open trade, the rule of law and the provision of international public goods is alien to Trump's way of thinking. Since assuming office in January 2017, he has instead made a virtue of unilateral action and national self-interest. Trump has withdrawn the US from both the Joint Comprehensive Plan of Action on Iran and the Trans-Pacific Partnership (TPP), given notice on the Paris Agreement on climate change and the Intermediate Nuclear Forces (INF) Treaty, defied international consensus by relocating the US embassy in Israel to Jerusalem, and imposed tariffs on allies (Canada and the European Union [EU]) and rivals (China) alike. Trump has also rubbished multilateral bodies such as the World Trade Organization (WTO) and the North American Free Trade Agreement (NAFTA) of which the US is a member, and criticised those such as the EU, the Organisation of Petroleum Exporting Countries (OPEC), and the International Criminal Court (ICC), of which it is not. These moves have been accompanied by a wilful disregard for diplomatic decorum. Trump has insulted sitting heads of allied governments in Canada, Germany, and the UK while steadfastly refusing to admonish infractions of international law by Russian and Saudi leaders.

Those dedicated to the liberal order have reacted to this behaviour with a mixture of pessimism, despair, and regret. ${ }^{4}$ Commentary in establishment organs such as The Economist, The Financial Times, The New York Times, Die Zeit, and Le Monde has been predictably and consistently critical of the Trump administration. More telling have been the reactions of America's allies. German Foreign Minister Sigmar Gabriel suggested in December 2017 that America's retreat from 'Western-influenced multilateralism' was 'accelerating the transformation of the global order'. ${ }^{5}$ Gabriel's successor, Heiko Maas, has noted that Trump's 'egoistic policy of "America First"' is as destabilising as Russia's disregard for international law and Chinese expansionism. ${ }^{6}$ And French president Emmanuel Macron has warned of the dangers of 'crude hegemony' and 'might makes right'. 'These views have paralleled those of figures within the US foreign policy establishment. During the 2016 election campaign, fifty former Republican national security officials declared that a Trump presidency would be the most reckless in American history. ${ }^{8}$ Criticisms by former senior intelligence, military, and national security officials - many with Republican Party affiliations - continued on similar lines following Trump's election. ${ }^{9}$

Disquiet at Trump's illiberalism, then, is profound. Yet two important caveats need to be borne in mind. First, Trump's position on many issues is declaratory only, confined to tweets, off-the-cuff remarks, and campaign rallies. Presidential comment is, of course, consequential in

\footnotetext{
${ }^{3}$ General Assembly of the United Nations, General Debate (25 September 2018), available at: \{https://gadebate.un.org/en/ 73/united-states-america\}.

${ }^{4}$ A characterisation derived from 'Present at the destruction', The Economist (9 June 2018), pp. 21-4.

${ }^{5}$ Speech at the Berlin Foreign Policy Forum (5 December 2017), available at: \{https://www.auswaertiges-amt.de/en/ newsroom/news/berliner-forum-aussenpolitik/909376\}.

${ }^{6}$ Speech in Berlin (13 June 2018), available at: \{https://bruessel-eu.diplo.de/eu-en/-/1354592\}.

${ }^{7}$ Cited in Julian Borger, 'Macron calls on members to resist new US "hegemony", The Guardian (8 June 2018).

${ }^{8 c}$ A letter from G.O.P national security officials opposing Donald Trump', The New York Times (8 August 2016), available at: $\{$ https://www.nytimes.com/interactive/2016/08/08/us/politics/national-security-letter-trump.html?module=inline $\}$.

${ }^{9}$ James Comey (former Director of the FBI), A Higher Loyalty: Truth, Lies and Leadership (London: Pan Macmillan, 2018); Michael V. Hayden (former Director of the CIA), The Assault on Intelligence: American National Security in an Age of Lies (New York: Penguin Press, 2018); Tim Weiner, 'The "witch hunters"', The New York Review of Books (16 August 2018), pp. $50-3$.
} 
its own right, but excessive attention to it (and Trump's bombast certainly invites scrutiny) gives rise to misplaced and unrealised presentiments of danger (a refusal to defend allies or 'the breakup of the Western political community'). ${ }^{10}$ Second, Trump has kept much of American foreign policy within familiar boundaries. The US has reaffirmed security guarantees to Japan and South Korea, supported the relationship with Saudi Arabia and pushed on with the types of special forces and drone operations in Africa and Pakistan that were favoured by both the Bush and Obama administrations. Trump has, admittedly, departed from Obama on the IsraelPalestine issue, in the muscularity of the campaign against ISIS, and in the commitment to raising the defence budget - but any one of these positions would, post-Obama, have fitted the Republican Party mainstream. ${ }^{11}$ An announced reduction of American forces in Afghanistan and the withdrawal of support for anti-ISIS operations in Syria in December 2018 went down badly with the Washington national security establishment (prompting the resignation of Secretary of Defense James Mattis) and reversed earlier commitments of the administration. But it was hardly outlandish, being in line with the longer-term trend (one instigated by Obama) of reducing America's overseas commitments borne of the catastrophe of the Iraq intervention. Keeping within the boundaries of policies past is not itself a marker of a commitment to order (backing the Saudi war in Yemen, for instance, hardly qualifies in that regard). That it signifies policy continuity, however, implies that some logic other than a desire to subvert is at play. Contrary to the view that Trump's personality places his actions in an 'ontological realm' outside of theory and explanation, ${ }^{12}$ a discernible pattern of policy has emerged, which brooks serious consideration.

Robert Jervis has suggested that the Trump administration's foreign policy can be viewed through 'the organizing scheme of levels of analysis'. ${ }^{13}$ By that division, much analysis of the administration falls within the Waltzian 'first image' - foreign policy being a reflection of Trump's personality, beliefs, and interests. Insofar as these characteristics are seen as unusual, then so too Trump's policies preferences are regarded as outliers and the urge to disrupt consensus becomes the signature of the Trump approach. However, as Waltz noted many years ago, the individual may wish to pursue a particular course of action but is constrained by his or her own 'selfishness [and] stupidity'. ${ }^{14}$ Here, Trump's predilections are explicable by reference to his upbringing, age, business background, conflation of the personal with the national interest, and sympathies with a nationalist, far-right agenda. ${ }^{15}$ That actual policy has not kept pace with these expressions of intent is, in turn, the outcome of Trump's inattentiveness, disregard of process, and lack of application. These sorts of explanation appear relevant precisely because Trump's behaviour is so compelling; the 'anxiety, comedy, theatre and outrage' that has characterised his presidency is an irresistible subject of analysis. But, as already noted, such analysis can place too much emphasis on Trump. The 'incessant scrutiny of Trump's personality, his statements, and his tweets' leads naturally, but mistakenly, to a view that the universe of policy is centred on one individual. $^{16}$

\footnotetext{
${ }^{10}$ For this type of thinking (and the source of the quotation), see Donald Tusk, 'The West must stand united at G-7', The New York Times (international print edition) (8 June 2018).

${ }^{11}$ Barry Posen, 'The rise of illiberal hegemony: Trump's surprising grand strategy', Foreign Affairs, 97:2 (2018), pp. 20-7.

${ }^{12}$ Michael N. Barnett, 'What is International Relations theory good for?', in Robert Jervis et al. (eds), Chaos in the Liberal Order: The Trump Presidency and International Politics in the Twenty-First Century (New York: Columbia University Press, 2018), p. 8.

${ }^{13}$ Robert Jervis, 'President Trump and International Relations theory', in Jervis et al. (eds), Chaos in the Liberal Order, pp. 3-7.

${ }^{14}$ Kenneth N. Waltz, Man, the State and War: a Theoretical Analysis (New York and London: Columbia University Press, 1959), p. 16.

${ }^{15}$ Barnett, 'What is International Relations theory good for?', pp. 16-19.

${ }^{16}$ Peter Viggo Jakobsen, 'Doomsday cancelled: Trump is good news for allies and world peace', War on the Rocks (2 March 2017), available at: \{https://warontherocks.com/2017/03/doomsday-cancelled-trump-is-good-news-for-allies-and-worldpeace/\}.
} 
Hence, the need to attend to two other levels of analysis. At the level of domestic politics Trump (at least until the 2018 mid-term elections overturned the Republican majority in the House of Representatives) enjoyed a largely free hand in his foreign policy dealings with Congress. What Stephen Walt has labelled the Washington 'foreign policy community' has proven more of an obstacle, however. ${ }^{17}$ This is a body Trump has blamed for a 'long history of failed policies', but it is not one he has managed to escape. While there has been considerable turnover of personnel, many key figures have been drawn from this group of privileged insiders whose record of government and military service long pre-dates Trump's political ascent. Marine Corps generals Jim Mattis (Trump's first Secretary of Defense) and John Kelly (Trump's second Chief of Staff) exemplify the establishment consensus on defence issues. The appointment in early 2018 of National Security Advisor John Bolton and Secretary of State Mike Pompeo, similarly, was hardly a break with orthodoxy, both figures being better characterised as American primacists and Republican hawks than Trump loyalists. ${ }^{18}$ If personnel choices have signalled a lack of intent to overhaul foreign policy then that tendency has also been evident in Trump's political neglect of those agencies - the State Department and the National Security Council - which might have spearheaded and coordinated such reform. ${ }^{19}$ That absence of coordination has been made that much worse by the well-reported in-fighting among senior administration officials. ${ }^{20}$

At the international (or systemic) level, finally, Trump's behaviour has been presented as a political phenomenon out of kilter with the responsibilities of global leadership. Here, 'America first' equates to 'America alone.. ${ }^{21}$ On Iran, Israel, and climate change that might be a fair characterisation. However, on a range of other issues - such as dealing with North Korea and confronting ISIS - the US cannot avoid working with allies or other powers such as China. ${ }^{22}$ Further, the US continues to enjoy 'positional advantages' within the international system measured by FDI flows, the status of the dollar as the global currency of choice, and the military balance of power. ${ }^{23}$ China is the obvious challenger here but even the most persuasive accounts of its global rise concede that a usurpation of Pax Americana is unlikely to occur for 'the next several decades (at least) ${ }^{24}$ This is an advantage, of course, which the Trump administration could squander, counterintuitively discounting the benefits of a system created to embed American leadership in light of its perceived costs. ${ }^{25}$ However, the international system is perhaps the most consequential constraint of all. Whatever Trump's disavowals, the US is deeply tied to a liberal order characterised by interdependence and institutionalisation. Breaking those ties Trump suggests is plausible; in practice it is extraordinarily difficult. ${ }^{26}$

That institutional influence also plays down to other levels of analysis. At the domestic level, Congress as well as officials in the administration, the bureaucracy, and the military will have views shaped by their experience of working with international institutions or will steer to habituated forms of thinking that continue to reference those same institutions as part of the

\footnotetext{
${ }^{17}$ Stephen Walt, The Hell of Good Intentions: America's Foreign Policy Elite and the Decline of US Primacy (New York: Farrar, Straus and Giroux, 2018), pp. 91-136.

${ }^{18}$ Walt, The Hell of Good Intentions, pp. 221-3, 249.

${ }^{19}$ Roberta S. Jacobson, 'My year as a Trump ambassador', The New York Times (international print edition) (22 October 2018).

${ }^{20}$ Bob Woodward, Fear: Trump in the White House (London: Simon and Shuster, 2018).

${ }^{21}$ Susan B. Glasser, 'Under Trump "America First” really is turning out to be America alone', The New Yorker (8 June 2018), available at: $\{$ https://www.newyorker.com/news/letter-from-trumps-washington/under-trump-america-first-really-isturning-out-to-be-america-alone\}.

${ }^{22}$ Jake Sullivan, 'The world after Trump: How the system can endure', Foreign Affairs, 97:2 (2018), p. 14.

${ }^{23}$ Stokes, 'Trump, American hegemony', pp. 142-5.

${ }^{24}$ Christopher Layne, 'The US-China power shift and the end of Pax Americana', International Affairs, 94:1 (2018), p. 108.

${ }^{25}$ Stokes, 'Trump, American hegemony', p. 149.

${ }^{26}$ Daniel Deudney and G. John Ikenberry, 'Liberal world: the resilient order', Foreign Affairs, 97:4 (2018), p. 22.
} 
foreign policy status quo. ${ }^{27}$ And even at the individual level, a president's worldview is shaped by judgements (even when hostile) on the institutional milieu within which s/he assumes to exercise influence.

In this light, two important, and related suggestions follow. First, international institutions can enable as well as constrain. They impose obligations and narrow options, but equally they provide a venue for the articulation and pursuit of preferences. Breaking loose from their influence may seem attractive, but such a course of action, by the same token, closes off the attendant opportunities for advancement. Expressed in Hirschman's well-known formulation, here 'voice' counts for as much as 'exit'. Second, the logic of policy moderation directly correlates with institutionalisation. ${ }^{28}$ The greater the degree of institutionalisation in the foreign policy domain in question, the (i) the more historically embedded is the US interest; (ii) the more plentiful are the opportunities for voice rather than exit; and (iii) the more open are the possibilities for compromise with allies. The US under Trump has thus found it easier to renounce commitments where institutionalisation is nascent (as in the Iran and Paris agreements and the aborted Trans-Pacific Partnership) than where it is well developed (as in the WTO, NAFTA, and the UN). ${ }^{29}$ Such a state of affairs is particularly noteworthy in the case of NATO. The Alliance is a cornerstone of liberal international order and emblematic of continuity in US foreign policy. It is also characterised by longevity, institutionally framed collaboration and coordination, as well as a history of US leadership and engagement. If a logic of constraint and moderation is to work anywhere, it should be here.

\section{Voice and exit in alliance}

Hirschman's model describes how actors respond to a decline in the performance of an organisation of which they are part. ${ }^{30}$ Decline might refer to organisational performance, but equally to how that organisation impacts upon an actor, how the benefits of membership diminish as a consequence of organisational dysfunction. In such circumstances, three options are available to the actor. The first, that of exit, arises when the actor accepts organisational deterioration as unavoidable and seeks to minimise its effects by withdrawing from the body in question. Voice, by contrast, aims at mitigating and even reversing decline by protest, complaint, and persuasion. Loyalty, finally, accepts decline, but the actor in question sticks with the organisation either because exit has greater costs or there is no alternative organisation to turn to. Refinement of

\footnotetext{
${ }^{27}$ Patrick Porter, 'Why America's grand strategy has not changed: Power, habit and the US foreign policy establishment', International Security, 42:4 (2018), pp. 13-19.

${ }^{28}$ Understood here as: (i) organisational procedures geared towards the performance of defined functions; and (ii) rules and procedures both formal and informal, which define how decisions are reached and which allocate responsibilities for the fulfilment of functions by the organisation's membership. See Celeste A. Wallander and Robert O. Keohane, 'Risk, threat, and security institutions', in Helga Haftendorn, Robert O. Keohane, and Celeste A. Wallander, Imperfect Unions: Security Institutions over Time and Space (Oxford: Oxford University Press, 1999), p. 28.

${ }^{29}$ The Trump administration has thus sought a revamp of NAFTA under the umbrella of the US-Mexico-Canada Agreement. This is an arrangement described as keeping 'NAFTA largely intact' (see Justin Worland, 'A NAFTA deal brings a return to status quo', Time (15 October 2018), p. 6). Trump has also suggested he would pull the US out of the WTO 'if they [sic] don't shape up'. Simultaneously, however, the US has made use of WTO mechanisms to challenge the trade practices of China, the EU, Canada, Mexico, and Turkey, and no formal procedures for leaving the body have been activated. As for the UN, the Trump administration has shown the same type of scepticism as previous Republican administrations, cutting contributions to the UN budget, withdrawing the US from the Human Rights Council, and announcing its intention to leave UNESCO. At the same time, however, the US has kept clear of any suggestion to reform the Security Council (so keeping its veto-power intact) and has freely used the General Assembly to promote Trump's foreign policy agenda.

${ }^{30}$ Albert O. Hirschman, Exit, Voice and Loyalty: Responses to Decline in Firms, Organisations, and States (Cambridge, MA and London: Harvard University Press, 1970), pp. 3-4.
} 
Hirschman's model has either added to these categories (the concept of 'neglect') or sought to reformulate them. ${ }^{31}$ What such analyses have in common is the view we take forward here, that exit and voice, while defined as distinct categories of action, often work in conjunction - voice, for instance, 'can be more effective if there is a threat of exit'. ${ }^{32}$ We accept that loyalty and voice could also work together. That we focus on exit's relationship with voice is simply a reflection of our case; unusually exit has been elevated as a possible course of action and so the default position of loyalty is less of an analytical concern.

Exit is risky, costly, and usually irreversible. Whether a substitute is available narrows down the circumstances in which it might occur. Exit is usually seen as most viable in the marketplace - a consumer is free to exit one product in favour of another. It may also apply in domestic politics - evident in how voters can switch between party affiliation in elections. However, in the world of international organisations, the options are fewer. Exit is feasible where an actor is powerful enough to have avoided organisational dependency and, by extension, can obtain a positive pay-off by breaking free of the constraints of membership. Within NATO, these conditions only pertain to the US. It is the threshold power. The effective and credible defence of the North Atlantic area remain dependent upon US military commitment and resources (both nuclear and conventional) that are absent or limited in Europe. Further, it could be argued that America's own security would not be seriously eroded if it were to leave NATO; neither would it need to have recourse to an alternative alliance system. The US could fall back on its ample national defence capabilities while exploiting the gains to be had from relinquishing the obligation to defend its needy allies.

If exit is a credible option for the US, why has it not taken place? The answer lies in the institutional character of the Alliance. Institutional analysis of NATO is often seen as a counter to realism. The latter views alliances as mechanisms of balancing or bandwagoning in the international system with alliance formation, stability, and durability being a reflection of power configurations among states. Realism can account for the formation of NATO, its cohesion when confronted with a commonly recognised existential threat such as the Soviet Union, and its adaptation after the Cold War as the US harnessed the Alliance to new security tasks. Here, what matters is national and especially American preferences not NATO's institutional qualities. ${ }^{33}$ Discounting institutions in this case is, however, misplaced. NATO's permanent mechanisms of intra-alliance political consultation alongside a standing command structure (embracing defence planning, standardisation, interoperability, and a recurrent rather than one-off ability to deploy) are unique among both historical alliances and contemporary international organisations. ${ }^{34}$ Two consequences follow from the presence of these arrangements. First, NATO has assumed an elevated status in American strategic calculations. Here, the burden of defending allies is offset by NATO's political role in aligning allied preferences with those of the US. NATO's institutional mechanisms (the North Atlantic Council above all) make that alignment possible, ensure it is embedded, and deliver efficiencies and gains to all allies in the process. NATO thus takes on alliance-centric tasks (the security of Europe and the stabilisation of its periphery) that are of clear benefit to Europeans but which provide, simultaneously, an important security externality to the US. Second, institutionalisation has assumed a social character - the sophistication and

\footnotetext{
${ }^{31}$ William Roberts Clarke, Matt Golder, and Sona N. Golder, 'An exit, voice and loyalty model of politics', British Journal of Political Science, 47:4 (2017); Brian Barry, 'Review article: “Exit, voice and loyalty", British Journal of Political Science, 4:1 (1974).

${ }^{32}$ Keith Dowding, Peter John, Thanos Mergoupis, and Mark Van Vugt, 'Exit, voice and loyalty: Analytic and empirical developments', European Journal of Political Research, 37:4 (2000), p. 472. See also Hirschman, Exit, Voice and Loyalty, p. 82.

${ }^{33}$ Jonathan Sireci and Damon Coletta, 'Enduring without an enemy: NATO's realist foundation', Perspectives, 17:1 (2009).

${ }^{34} \mathrm{Paal}$ Sigurd Hilde, 'Lean, mean fighting machine? Institutional change in NATO and the NATO command structure', in Andrew A. Michta and Paal Sigurd Hilde (eds), The Future of NATO: Regional Defence and Global Security (Ann Arbor: University of Michigan Press, 2014), pp. 135-54.
} 
permanency of intra-alliance mechanisms provide ample opportunities for voice and renders that articulation legitimate. One need not characterise NATO as a community organisation of democratic values ${ }^{35}$ in order to allow for this outcome. It can be seen also as the consequence of more formal properties that pertain to a sophisticated multilateral security arrangement: acceptance of the principle of consultation, agreement on common security threats and, in NATO's case, a sense of shared endeavour built up over a decades' long history. ${ }^{36}$ These properties are certainly open to exploitation. However, even the most powerful ally will be wont to play within the multilateral rules of the game. These, after all, are stacked in its favour and so offer a reliable means of exercising leadership and getting fellow allies to toe the line. ${ }^{37}$

All of this is not simply realism by another route. Institutions act as a vehicle within which the demands of the powerful are articulated and modified. The institution, in other words, exerts its own effect. The interaction of exit and voice in NATO bears out this assumption. A member as powerful as the US could well hold the view that NATO is underperforming its core defence function or is neglecting other tasks the US considers important. Equally, it might believe that the cost of contributing to NATO's public security goods is too great particularly if other allies are seen to be shirking their responsibilities. America's history of engagement with NATO has been characterised by the periodic recurrence of such tensions yet, as we shall see below, throughout it has exercised the option of voice. Voice has proven effective both in expressing dissatisfaction with NATO's allies and advocating changes to allied business. NATO's institutionalisation, in other words, has served to minimise the cost, and to maximise the benefits of exercising voice, just as it has served to minimise the benefits and to maximise the cost of exit. ${ }^{38}$

\section{Institutional effects}

Three specific institutional effects associated with NATO illustrate more precisely why voice is preferred to exit. In this section we survey these as trends over time as they affect the US. We then turn to the policy of the Trump administration to show how the proclivity for voice has persisted.

\section{Institutional pull}

The first of these effects is institutional pull, the enduring attractiveness of NATO to the US. We have already alluded to NATO's institutional qualities, but of note here is how these have been bent to American design. That advantage is an enduring consequence of the asymmetry of power that has characterised the Alliance since its formation in 1949. NATO's functioning in the Cold War, Robert Osgood argued, was premised on the fact that 'no group of allies' was capable of acquiring 'independently of the United States, an adequate military basis for protecting its vital interests' ${ }^{39}$ That state of affairs has persisted. The end of the Cold War resulted in a significant drawdown of US forces in Europe, but as of September 2018 there were still approximately sixtyfour thousand active US service personnel on the continent. In fact, with the end of US combat missions in Iraq and Afghanistan, a Cold War pattern has reasserted itself: US troops are again

\footnotetext{
${ }^{35}$ Frank Schimmelfennig, The EU, NATO and the Integration of Europe: Rules and Rhetoric (Cambridge: Cambridge University Press, 2003).

${ }^{36}$ Helen Sjurson, 'On the Identity of NATO', International Affairs, 80:4 (2004), pp. 699-701.

${ }^{37}$ Vincent Pouliot, International Pecking Orders: The Politics and Practice of Multilateral Diplomacy (Cambridge: Cambridge University Press, 2016), pp. 59-66.

${ }^{38}$ Kirsten Rafferty, 'An institutionalist reinterpretation of Cold War alliance systems: Insights for alliance theory', Canadian Journal of Political Science, 36:2 (2003), pp. 344-52.

${ }^{39}$ Robert Endicott Osgood, NATO: the Entangling Alliance (Chicago and London: University of Chicago Press, 1962), p. 348.
} 
concentrated in East Asia and Europe (Japan, Germany, South Korea, and Italy being the top four locations of US forces overseas). ${ }^{40}$

NATO operations - both in and beyond Europe - have also reflected America's military weight. Interventions in Bosnia, Kosovo, and Libya would simply not have been possible if run by European allies. NATO's reaction to the 2014 Ukraine crisis prompted an upscaling of European effort but European forces have remained constrained by years of under-investment. One recent study has suggested that 'the major European allies would be hard-pressed to provide one combat-capable brigade at short notice', whereas the US even in Europe 'is set to have three combat brigades ... present at all times'. ${ }^{41}$ France, the UK, Germany, and some other allies may have developed niche capabilities in cyber, special operations, and drones, but in these regards also none can match the US in the scale and sophistication of military effort. NATO, in effect, has been the institutional means by which these differences have been accommodated. Allied defence planning has been one long exercise aimed at obtaining European interoperability with America's quantitative and qualitative military advantages. That NATO's Supreme Allied Commander Europe (SACEUR) has always been an American (the post being double-hatted with that of the Commander-in-Chief of US forces in Europe) is further evidence of European deference to American military power and priorities.

NATO is attractive to the US not simply because it is a collection of supplicant allies, but because it harnesses those allies in a predictable and sophisticated manner. NATO is the mechanism that ensures military interoperability of European and Canadian forces with those of the US, embeds a sophisticated command and planning structure that favours US oversight of the European theatre of operations, and shapes the national security priorities of its members consistent with American strategic objectives. Recognising these virtues, the US has an interest in NATO's sustainment. It has, therefore, pursued policies that, while attuned to US interests, are also designed to add credibility to NATO itself. For instance, NATO nuclear sharing is an arrangement less to do with 'the deterrence of adversaries' and more with 'catalyz[ing] agreements about broader strategy' among allies. ${ }^{42}$ In Afghanistan, NATO-ISAF was eventually folded into a US-led command structure and so the alliance and American fortunes were conjoined in the anti-Taliban campaign. ${ }^{43}$ The US military response to the 2014 Crimea crisis was similarly framed by a NATO position aimed at deterring further Russian aggression.

\section{Institutional bargaining}

The advantages the US has enjoyed in NATO have, however, come at a price. Institutions aggregate and distribute resources among their members and clients. But where the provision of a public good is subject to a significant asymmetry of supply, an incentive towards free-riding arises. ${ }^{44}$ In NATO, the dependency of the European and Canadian allies that underpins this dynamic has not always been unwelcome to the US. It has ensured Germany's anchoring within a European alliance system and, in the guise of extended deterrence, has curtailed nuclear proliferation in western Europe. ${ }^{45}$ More problematic for the US has been the reluctance of many allies to develop conventional capabilities able to contribute to the collective NATO effort. To

\footnotetext{
${ }^{40}$ Defence Manpower Data Centre, 'Number of Military and DoD Appropriated Fund (AFP) Civilian Personnel Permanently Assigned' (September 2018), available at: \{https:/www.dmdc.osd.mil/appj/dwp/dwp_reports.jsp\}.

${ }^{41}$ Martin Zapfe, 'Threatened from within? NATO, Trump and institutional adaptation', in Oliver Thränert and Martin Zapfe (eds), Strategic Trends 2017: Key Developments in Global Affairs (Centre for Security Studies, ETH Zurich, 2017 ), p. 91.

${ }^{42}$ Stephan Frühling and Andrew O'Neil, 'Nuclear weapons, the United States and alliances in Europe and Asia; Toward an institutional perspective', Contemporary Security Policy, 38:1 (2017).

${ }^{43}$ Sten Rynning, NATO in Afghanistan: the Liberal Disconnect (Stanford, CA: Stanford University Press, 2012), pp. 176206.

${ }^{44}$ Todd Sandler and Keith Hartley, The Political Economy of NATO: Past, Present and into the $21^{\text {st }}$ Century (Cambridge: Cambridge University Press, 1990), pp. 22-57.

${ }^{45}$ Alexander Lanoszka, 'Do allies free ride?', Survival, 57:3 (2015), pp. 137-8.
} 
address that issue during the Cold War, NATO adopted a range of input measures (most notably, the target share of national GDP devoted to defence) aimed at equitable burden sharing. A flawed measure in many ways (the larger GDP share spent by the US reflected its global responsibilities not simply its commitment to NATO and European defence) it served nonetheless to sustain complaints from American presidents (all the way from Eisenhower to Reagan) and Congress of a lack of allied commitment. ${ }^{46}$ In fact, European dependence on US military effort became selfreinforcing, lowering incentives towards European force development and integration. European armies according to Henry Kissinger were 'an accidental array of forces' incapable of guaranteeing regional defence. Here, America's military presence in Europe was effectively held hostage to European weakness. ${ }^{47}$ As a result, the US developed a resentful but also proprietorial attitude towards NATO. In distinctly Trumpian language, Kissinger described the US view of the Alliance as one in which influence 'should be calculated in direct proportion to a nation's material contribution to the common effort' ${ }^{48}$

NATO's burden-sharing problem became more multifaceted after the Cold War. The shift to peacekeeping and expeditionary missions introduced new ways of measuring military commitment. Output measures - the material contribution to operations, the deployability and sustainability of military assets, the willingness to share the risk of combat and counterinsurgency loomed large through Bosnia, Kosovo, Libya, and Afghanistan. ${ }^{49}$ Familiar American complaints followed. Bill Clinton's Defense Secretary, William Cohen, charged in 1999 that the 'disparity of alliance capabilities' on display during Operation Allied Force, coupled with the reluctance of states such as Germany to invest in defence, placed NATO's unity at risk. ${ }^{50}$ The Bush administration, meanwhile, complained at the paucity of allied efforts in Afghanistan (with ire again directed at Germany owing to its reluctance to engage in counterinsurgency). Donald Rumsfeld, George W. Bush's first-term Secretary of Defense, suggested in a classified 2004 memorandum that NATO was one of a number of international organisations (along with the World Bank and the International Monetary Fund) whose purpose had become exhausted and which could usefully be replaced. 'Too often', Rumsfeld later reflected, the US military had been 'burdened with the responsibility' of dealing with crisis because the armed forces of its allies were not up to the job. ${ }^{51}$ In a similar vein, President Obama would suggest some years later that US support for NATO's 2011 intervention in Libya had been a mistake as British and French commitments to stabilising the country had not materialised. ${ }^{52}$

In part, these charges were exaggerated. In Afghanistan, for instance, the UK, Denmark, and the Baltic States had paid a high price in blood and treasure in a counterinsurgency campaign that meant little to their own national security interests. ${ }^{53}$ Equally, in Bosnia and Kosovo, once critical US-led aerial combat operations had concluded, it was Europeans who made up the lion's share of NATO peacekeeping operations. However, for all the emphasis on outputs such as these, the GDP spend target retained a totemic significance. And it appeared to highlight a manifest inability in Europe to invest in the sort of advanced military equipment and training that would

\footnotetext{
${ }^{46}$ Alan Tonelson, 'NATO burden-sharing: Promises, promises', Journal of Strategic Studies, 23:3 (2000).

${ }^{47}$ Henry Kissinger, The White House Years (London: George Weidenfeld and Nicolson, 1979), pp. 82-3.

${ }^{48}$ Henry Kissinger, Diplomacy (London: Simon and Shuster, 1994), p. 603.

${ }^{49}$ Jens Ringsmose, 'NATO burden-sharing redux: Continuity and change after the Cold War', Contemporary Security Policy, 31:2 (2010).

${ }^{50}$ William Drozdiak, 'Cohen says Europe must boost defence spending', Washington Post (1 December 1999), available at: \{www.washingtonpost.com/wp-srv/pmextra/dec99/1/ciohen.htm\}.

${ }^{51}$ Donald Rumsfeld, Known and Unknown: A Memoir (New York: Sentinel, 2011), pp. 623-4.

${ }^{52}$ Mark Landler, 'Obama criticizes "free rider" allies', The New York Times (international print edition) (11 March 2016).

${ }^{53}$ James Sperling and Mark Webber, 'NATO: from Kosovo to Kabul', International Affairs, 85:3 (2009), p. 508.
} 
keep NATO's allies interoperable with the US. ${ }^{54}$ The precipitate drop in European defence spending following the 2008 financial crash added to American concerns. US Secretary of Defense Robert Gates made a well-reported intervention in 2011 claiming that NATO's very future was in doubt because of European under-investment. ${ }^{55}$

By the time of NATO's 2014 Wales summit the US share of total NATO defence expenditure stood at 73 per cent (how disproportionate that sum appeared is evident from the fact that the US share of total NATO GDP was significantly lower at just over 45 per cent). ${ }^{56}$ The urgency provided by the Ukraine crisis resulted in the allies recommitting at Wales to a defence spending target of 2 per cent of GDP (to be achieved at the latest by 2024). At that time, only the US, the UK, and Greece met the mark. Obama would claim shortly before departing office that 'free riders aggravate me' and that even allies such as the UK had no right to claim a special relationship with the US if they failed to meet NATO's defence spending target. ${ }^{57}$

Burden sharing, historically, has been only one of many issues that has prompted American dissatisfaction at NATO. Divisions over American adventures abroad (Vietnam and Iraq), nuclear strategy or how to deal with the Soviet Union/Russia have episodically impacted on transatlantic relations. Burden sharing is different in that it has been a constant background noise. The ingrained nature of the dispute has, however, rendered it manageable. As Wallace Thies has suggested, in a permanent, integrated alliance plentiful opportunities exist 'to affect decisions concerning costs and benefits'. '[R] egularized channels for bargaining' have developed serviced by a committed bureaucracy, focused on a defence planning process, and underpinned by a set of alliance-wide norms. This has meant the desirability (if always not the reality) of burden sharing is beyond question. Two important consequences follow from this institutional context. First, there is a legitimacy to American demands for increased effort among allies. Second, the greater political, diplomatic, and military resources that the US possesses give it a clear advantage in bargaining. This does not always translate into a preferred outcome; allies will, after all, use their own limited bargaining power to shift if not share the burden of defence. However, the 'indispensability' of the American contribution mean the US has been able 'to pursue again and again a redistribution of burdens' and to 'compel [its] smaller allies to do things [... they] would prefer to avoid'. ${ }^{58}$

In short, NATO is a framework within which burden sharing and other transatlantic disputes play out. These disputes, over time, acquire a predictable, even choreographed quality. US presidents, officials, and congressional representatives complain at the NATO allies' deficiencies in defence and lack of strategic ambition. The attendant warnings of NATO decline and division, however, are blunted by the advantages that regularised bargaining give to voice rather than to exit. And cycles of frustration ensue as each administration discovers, seemingly anew, both the burdens and benefits of the Alliance.

\footnotetext{
${ }^{54}$ David S. Yost, 'The US - European capabilities gap and the prospects for ESDP', in Jolyon Howorth and John T. S. Keeler (eds), Defending Europe: The EU, NATO and the Quest for European Autonomy (New York: Palgrave Macmillan, 2003), pp. 83-95.

${ }^{55}$ 'Remarks by Secretary Gates at the Security and Defence Agenda, Brussels, Belgium' (10 June 2011), available at: \{http:// archive.defense.gov/Transcripts/Transcript.aspx?TranscriptID $=4839\}$.

${ }^{56}$ Figures calculated from NATO Public Diplomacy Division, 'Defence Expenditure of NATO Countries (2010-2017)', Press Release PR/CP (2017) 111, Graph 7 and Table 4, available at: \{https://www.nato.int/nato_static_fl2014/assets/pdf/ pdf_2017_06/20170629_170629-pr2017-111-en.pdf\}.

${ }^{57}$ Jeffrey Goldberg, 'The Obama doctrine: the US president talks through his hardest decisions about America's role in the world', The Atlantic (April 2016), available at: \{https://www.theatlantic.com/magazine/archive/2016/04/the-obama-doctrine/ 471525/\#8\}.

${ }^{58}$ Wallace J. Thies, Friendly Rivals: Bargaining and Burden-Shifting in NATO (M. E. Sharpe: Armonk, New York, 2003), pp. 3-13, 274.
} 


\section{Institutional adaptation}

How and to what extent political actors can influence institutional adaptation is a fundamental question of institutionalist analysis. Any enquiry based on voice must assume that the actor believes it can be an agent of change. Such an agential approach does, of course, run contrary to the view that social, political, and historical obstacles to innovation matter more, working either to channel change or to subvert it. There is no general rule as to whether institutions constrain or empower actors - the institutional setting, the external environment, and the nature of the agent matter differently in discrete contexts. ${ }^{59}$

But in NATO's case, at least, the empirical record is clear: US leadership has been the determining factor behind almost every action of consequence. NATO's consensus-based decision-making does not allow the US to simply impose a position - agreed outcomes require diplomatic cultivation and, at times, extended efforts at persuasion. But this has been a process that has mirrored and only rarely frustrated US preferences. During the Cold War, NATO nuclear strategy along with the periodic shifts from détente to contestation in relations with the Soviet Union, reflected a seemingly artful balance of American and west European priorities, but one that ultimately accorded with US standing as 'primus inter pares in European security affairs'. ${ }^{60}$ That standing has endured in the decades since. NATO's very survival at the end of the Cold War owed much to the George H. W. Bush administration's articulation of a European security architecture capped by a transformed alliance. This position (supported by the British) saw off alternatives premised on a reinvigorated Conference on Security and Cooperation in Europe (supported by the German Foreign Ministry) and a nascent EU defence arrangement (supported by France). ${ }^{61}$ Other US-led initiatives followed. The NATO-Russia Founding Act of 1997, owed much to the shuttle diplomacy of NATO Secretary Javier Solana, but would not have been possible without the indefatigable efforts of US envoy Strobe Talbott backed by President Bill Clinton. ${ }^{62}$ NATO's first big wave of enlargement in 1999 was the consequence of a complex three-pronged strategy (reassuring Russia, building consensus in NATO, and placing enlargement within a broader vision for the Alliance) orchestrated in Washington, DC. ${ }^{63}$ Transatlantic relations soured under George W. Bush, and NATO faced its worst post-Cold War crisis over Iraq in 2003. But the repair was swift. In August 2003, NATO assumed oversight of the International Security Assistance Force (ISAF) in Afghanistan and so entered America's long war against terrorism. In March 2004, NATO underwent its largest enlargement to date following the Bush's administration's commitment to the policy. Under Barack Obama the parallelism between US foreign policy and NATO's goals continued. The administration's 'reset' in relations with Russia mirrored efforts in the Alliance to resuscitate the work of the NATO-Russia Council. NATO's adoption in 2010 of missile defence as part of collective defence, along with the 2012 Deterrence and Defence Posture Review with its reaffirmation of NATO's nuclear force posture were also initiatives engineered in accordance with US priorities. ${ }^{64}$ NATO's response to the Ukraine crisis, finally, was facilitated by the Obama administration's public resolve to defend NATO's East European members. ${ }^{65}$

\footnotetext{
${ }^{59}$ For an overview of the relevant literature, see Vivien Lowndes and Mark Roberts, Why Institutions Matter: the New Institutionalism in Political Science (Houndmills, Basingstoke and New York: Palgrave Macmillan, 2013), pp. 111-43.

${ }^{60}$ Magnus Petersen, 'The United States as the reluctant ally', Parameters, 46:1 (2016), p. 44.

${ }^{61}$ Kori Schake, 'NATO after the Cold War, 1991-1995: Institutional competition and the collapse of the French alternative', Contemporary European History, 7:3 (1998).

${ }^{62}$ Strobe Talbott, The Russia Hand: A Memoir of Presidential Diplomacy (New York: Random House, 2002), pp. 217-50.

${ }^{63}$ Ronald Asmus, Opening NATO's Door: How the Alliance Remade Itself for a New Era (New York: Columbia University Press, 2002), pp. 289-305.

${ }^{64}$ Stéfanie Von Hlatky, 'NATO’s Chicago summit: Alliance cohesion above all else?', CSS Analysis in Security Policy, 116 (2012).

${ }^{65}$ James Sperling and Mark Webber, 'NATO and the Ukraine crisis: Collective securitisation', European Journal of International Security, 2:1 (2017).
} 


\section{Exit, voice, and the Trump administration}

American complaints directed at NATO have multiplied and become more shrill since the 2016 US presidential election. Given other transatlantic disagreements - on trade, Iran, and climate change - and the open admonishment Trump has directed at America's Canadian and European allies on each of these issues, then so the argument runs NATO's future 'looks shakier now than at any time since its inception in 1949'. ${ }^{66}$ But NATO's staying power and benefit to the US has become clear even to a foreign policy neophyte such as Trump. His apparent hostility to NATO reflects a strategy not of exit, but of voice.

\section{Exit?}

Trump's pronouncements indicate a seemingly long-held scepticism towards NATO. On burden sharing, Trump has a track record going back to the late 1980s, but comments in 1987 that NATO was 'taking tremendous advantage of the US' and that the allies 'should pay their way' ${ }^{67}$ were mild by comparison with positions struck in the 2016 presidential campaign. NATO, Trump suggested, was full 'of countries getting a free ride'. His solution was stark: either allies 'pay up, including for past deficiencies, or they have to get out. And if that breaks up NATO, it breaks up NATO. ${ }^{68}$ Seemingly abandoning at a stroke the US commitment to European security, Trump compounded the matter by calling into question NATO's very purpose. The Alliance, he claimed, was 'obsolete' in view of its poor record on terrorism - 'NATO doesn't discuss terrorism, [isn't] meant for terrorism, [and ...] doesn't have the right countries in it for terrorism.' It would thus either have to be 'readjusted to take care of terrorism' or replaced by a 'new coalition ... of countries' to deal with the issue. ${ }^{69}$ Equally significant, when asked if the US should defend NATO's Baltic allies in the face of Russian aggression, Trump said it depended on whether those countries had 'fulfilled their obligations to us'. ${ }^{70}$ This, The New York Times reported 'appeared to be the first time that a major candidate for president had laid down conditions for the defence of the United States' major allies. ${ }^{, 71}$ And those allies also came in for some specific criticisms. Germany and France were 'totally compromised by terrorism' because of their open immigration policies, ${ }^{72}$ Turkey lacked commitment in the fight against ISIS, ${ }^{73}$ and the Belgian capital had become a 'hellhole' because of immigrants and crime. ${ }^{74}$ These views were all the more worrying because of Trump's sympathies towards Russia. Trump conceded that

\footnotetext{
${ }^{66}$ Fraser Nelson, 'Next up, NATO', The Spectator (16 June 2018), p. 10. For similar reporting, see Charlotte McDonaldGibson, 'Is NATO Trump's next target?', Time (9 July 2018), p. 6; and Roger Cohen, 'Of course, it could not happen here', The New York Times (international print edition) (29 June 2018).

${ }^{67}$ Cited in Charlie Laderman and Brendan Simms, Donald Trump: The Making of a Worldview (London and New York: I. B. Tauris, 2017), p. 120.

${ }^{68}$ Cited in Steve Holland, 'Trump bashes US-Saudi Arabia relations, slams NATO allies', Reuters (2 April 2016), available at: $\{$ https://af.reuters.com/article/worldNews/idAFKCN0WZOSX\}.

${ }^{69}$ Interviewed on ABC News by Jonathan Karl (March 2016), available at: \{https://www.realclearpolitics.com/video/ 2016/03/27/trump_europe_is_not_safe_lots_of_the_free_world_has_become_weak.html\}.

${ }^{70}$ Cited in David E. Sanger and Maggie Haberman, 'Trump casts doubt over US pledges to its allies', The New York Times (international print edition) (22 July 2016).

${ }^{71}$ David E. Sanger and Maggie Haberman, 'Donald Trump sets conditions for defending NATO allies against attack', The New York Times (20 July 2016), available at: \{https://www.nytimes.com/2016/07/21/us/politics/donald-trump-issues.html\}.

${ }^{72}$ Cited in The Telegraph (24 July 2016), available at: $\{$ http://www.telegraph.co.uk/news/2016/07/24/donald-trump-saysfrench-and-germans-to-face-extreme-vetting-ent/\}.

${ }^{73}$ The Telegraph (2 July 2016), available at: \{http://www.telegraph.co.uk/news/2016/07/02/donald-trump-to-turkishreporter-are-you-friend-or-foe/\}.

${ }^{74}$ Cited in Dan Bilefsky and Claire Barthelemy, 'Donald Trump finds new city to insult: Brussels', The New York Times (27 January 2016), available at: \{https://www.nytimes.com/2016/01/28/world/europe/trump-finds-new-city-to-insult-brussels. html?_r=0\}.
} 
Russia was a threat, but referred to President Putin as a better leader than Barack Obama, and to Moscow's policy of support for the Assad regime in Syria as an effective means of dealing with ISIS. $^{75}$

It was no wonder that the allies awoke to a Trump electoral victory with a sense of foreboding. 'The American umbrella over Europe is gone forever' warned one former German ambassador to NATO. A German staff officer at NATO HQ went further, claiming 'a withdrawal from NATO by the United States is on the table, or at least a threat'. ${ }^{76}$ Trump's early moves in office did not allay these concerns. He repeated the assertion that NATO was 'obsolete ${ }^{\text {,77 }}$ and at the NATO leaders' meeting in May 2017 refused to endorse NATO's Article Five collective defence commitment. This prompted German Chancellor Angela Merkel to comment that 'we Europeans' could no longer rely on the US and should 'take our fate into our own hands'. German Foreign Minister Sigmar Gabriel was more blunt - Trump, he declaimed, was 'putting peace in Europe at risk'. ${ }^{78}$

At the NATO summit the following year, Trump's complaints were repeated. Letters sent in the president's name just before the event admonished the leaders of several allies for failing in their defence commitments. Germany was singled out, its 'underspending on defence' seen as 'undermin[ing] the security of the alliance'. A state of affairs in which 'some countries do not share NATO's collective security burden' 'was no longer sustainable' to the US, Trump insisted. ${ }^{79}$ At the summit itself, Trump, without warning, suggested that NATO's defence spending target should increase to 4 per cent of GDP, and that all allies should raise their spending by January 2019 otherwise 'the United States would go it alone'. ${ }^{80}$

This episode prompted two observations of note. First, Trump's bromides against NATO were seen as part of a wider assault on individual allies. Trump himself fuelled such an interpretation. Germany, he claimed, was 'captive' to Russia; the UK was pursuing an 'unfortunate' approach to Brexit, and Canadian Prime Minister Justin Trudeau was 'dishonest and weak'. ${ }^{81}$ Second, Trump's hostility was indicative of a 'radical [new] way of thinking about allies'. Most NATO members because they were also in the EU were in Trump's mind viewed more as competitors than allies. As such, they were not merely a drain on the US but actually harmful to American interests. ${ }^{82}$ Exit would seem to follow logically from such a position. The record of the Trump period, however, has been the opposite - a consolidation of America's commitment to NATO.

\section{Voice}

Like administrations before it, that of Donald Trump has taken a lead in the adaptation of NATO and has utilised the Alliance to sustain America's key security relationship with Europe. Entirely counter to Trump's complaints at burden sharing, it has also increased long-term investment in

\footnotetext{
${ }^{75}$ Politico (10 October 2016), available at: $\{$ https://www.politico.com/story/2016/10/trump-praise-russia-iran-assad-criticism-229546\}.

${ }^{76}$ Spiegel Online (16 November 2016), available at: $\{$ http://www.spiegel.de/international/world/worry-grows-over-trumpthreat-to-european-security-a-1121536.html\}.

${ }^{77}$ Full transcript of interview with Donald Trump', The Times (16 January 2017), available at: \{https://www.thetimes.co. uk/article/full-transcript-of-interview-with-donald-trump-5d39sr09d\}.

${ }^{78}$ Cited in Eugene Scott, 'Trump keeps up criticism of Germany', CNN (30 May 2017), available at: \{http://edition.cnn. com/2017/05/30/politics/trump-germany-merkel-trade/index.html\}.

${ }^{79}$ Julie Hirschfeld Davis, 'Trump warns NATO allies to spend more on defence, or else', The New York Times (2 July 2018), available at: $\{$ https://www.nytimes.com/2018/07/02/world/europe/trump-nato.html\}.

${ }^{80}$ The demands were made in private session but widely reported. See, for instance, Ewen MacAskill, 'True or bluff, Trump's "go it alone” bombshell causes dismay", The Guardian (13 July 2018).

${ }^{81}$ Demetri Sevastopulo and Michael Peel, 'Trump plays disrupter-in-chief on Europe trip', Financial Times (14-15 July 2018); Dan Bilefsky and Catherine Porter, 'Trump's “bully” attack on Trudeau outrages Canadians', The New York Times (10 June 2018), available at: \{https://www.nytimes.com/2018/06/10/world/canada/g-7-justin-trudeau-trump.html\}.

${ }^{82}$ Uri Friedman, 'Trump vs. NATO: It's not just about the money', The Atlantic (12 July 2018), available at: \{https://www. theatlantic.com/international/archive/2018/07/trump-nato-allies/564881/\}.
} 
NATO. The administration's first budget request to Congress included $\$ 4.8$ billion in funding for the European Deterrence Initiative (EDI) (a \$1.4 billion increase over 2017), the funding stream for measures to 'support ... the collective defence of [the] NATO Allies' in light of Russia's annexation of Crimea. ${ }^{83}$ The second budget request - approved by Congress and signed into law by Trump in August 2018, saw EDI funding (for financial year 2019) increase to $\$ 6.5$ billion. $^{84}$ Begun under Obama, EDI and its offshoot Operation Atlantic Resolve have seen an increase in the rotational deployment of US troops in Europe (along with the pre-positioning of military equipment) as well as support for NATO exercises and infrastructural and capacity-building measures for allies, particularly those such as the Baltic States, Poland, Bulgaria, and Romania on NATO's eastern flank.

Furthermore, in April 2017, the US army took command of a multinational battlegroup in Poland under the umbrella of NATO's Enhanced Forward Presence and formed the largest component of a new NATO multinational force in Romania launched in October. The US has also upheld its commitment to NATO ballistic missile defence, while in October to November 2018, some 20,000 US personnel took part in Trident Juncture, NATO's largest military exercise since 2015. Commensurate with these measures, the force posture of the US European Command (EUCOM) has remained attuned to its 'historic role' of deterrence, defence, and 'the steadfast' protection of the NATO allies' 'territorial integrity'. ${ }^{85}$ Three authoritative defence policy statements released at the end of Trump's first year in office, meanwhile, referred to NATO in familiar terms: as one of the 'great advantages' over America's competitors (Russia and China included), as 'vital to (American) security' and the subject of 'unwavering' 'US commitment'. ${ }^{86} \mathrm{At}$ NATO meetings, the US has also played the constructive ally. The November 2017 Defence Ministerial agreed to a new Atlantic command to be stationed in Norfolk, Virginia. The summit of July 2018 saw agreement on a US-backed NATO Readiness Initiative as well as a new training mission in Iraq and a Declaration on Transatlantic Security and Solidarity (cleared in Washington, DC), which reaffirmed NATO's 'bedrock commitment' to collective defence. At the Defence Ministerial in October 2018, the US confirmed it would make available resources in support of the newly established NATO Cyber Operations Centre.

This ongoing attachment to NATO could be seen as separated from Trump's own positions the work of Secretary of Defense James Mattis and the policy establishment in the State Department and the Pentagon where the familiar language of leadership and commitment has prevailed. $^{87}$ Equally, it may be a consequence of Trump's own inattention to detail. He is ignorant of the scale of the American military commitment to Europe and has shown no desire to shape NATO summit declarations (he reportedly didn't even read the documents agreed at the 2018 meeting). Yet ignorance, or for that matter, a lack of diplomatic etiquette does not mean an absence of purpose on Trump's part. Trump's criticism of allies, while crude, reflects a powerful premise of American policy - that allies are reluctant to spend on defence. His incessant focus on

\footnotetext{
${ }^{83}$ For the relevant measures and costings, see US European Command Public Affairs Office, '2018 European Deterrence Initiative (EDI) Fact Sheet' (October 2017), available at: \{www.eucom.mil\%2Fmedia-library\%2Farticle\%2F36102\%2F2018european-deterrence-initiative-edi-fact-sheet\&usg=AOvVaw0T jM0abUYUBVkU3XJOqX_i\}.

${ }^{84}$ Pat Towell and Aras D. Kazlauskas, 'The European Deterrence Initiative: A Budgetary Overview', In Focus (Congressional Research Service, 8 August 2018).

${ }^{85}$ Comments of EUCOM Deputy Commander, Lt Gen. Timothy Ray, at the OSCE Structured Dialogue, Vienna (6 June 2017), available at: $\{$ http://www.eucom.mil/media-library/transcript/35731/eucom-deputy-commander-lt-gen-timothy-rayon-current-trends-in-military-force-posture\}.

${ }^{86}$ National Security Strategy of the United States of America (December 2017), p. 48, available at: \{https://www.whitehouse. gov/wp-content/uploads/2017/12/NSS-Final-12-18-2017-0905.pdf\}; Summary of the National Defence Strategy of the United States of America: Sharpening the American Military's Competitive Edge (US Department of Defense, January 2018), p. 9, available at: \{https://www.defense.gov/Portals/1/Documents/pubs/2018-National-Defense-Strategy-Summary.pdf\}; predecisional draft of the Nuclear Posture Review (US Department of Defense, January 2018), extracted in Huff Post, available at: $\{$ http://www.huffingtonpost.co.uk/entry/trump-nuclear-posture-review-2018_us_5a4d4773e4b06d1621bce4c5\}.

${ }^{87}$ For this argument, see Woodward, Fear, pp. 76-9.
} 
burden sharing, meanwhile, has (in Trump's view) reaped rewards. While defence spending increases go back to the 2014 Ukraine crisis, announced increases in 2017 and 2018, Trump has suggested, are a direct consequence of his interventions. ${ }^{88}$ This is claiming credit where it may not be due, but it is certainly consistent with a strategy of voice and the logic of alliance politics. Trump, by alluding to the possibility of American exit, has confronted the NATO allies with the possibility of abandonment so adding urgency to defence spending plans. Even allies such as Canada, Germany, and France, which reject the claims of American influence, have been forced to publicly justify defence spending as if Trump's position on the matter was decisive. ${ }^{89}$ The most significant spending increases have occurred in exposed eastern European countries (the Baltics, Poland, and Romania) and it remains the case that the bigger spenders such as Germany and Italy have no intention of meeting the 2024 target. But the US under Trump has effectively ratcheted up the terms of debate and ensured that burden sharing has become the signature political issue of intra-alliance politics.

The seeming contradiction between Trump's disdain of allies and the increased material commitment of the US military to defend them may simply be that - a policy inconsistency, of a piece with the many other examples of incoherence emanating from the Trump White House. Yet contradiction, as we noted at the outset, may camouflage an underlying logic. Scepticism of NATO implies an exit from the Alliance, which Trump, more so than previous American presidents, has articulated as a plausible route for the US. That the commitment to NATO has endured nonetheless, communicates the stakes involved and gives the US the right to insist that allies follow America's example. Further, Trump's own sense that he has persuaded these countries to change course means he has acquired a personal stake in NATO's affairs. Amid all the criticism, Trump has talked up the Alliance's virtues ('I said it was obsolete. It is no longer obsolete.') and has affirmed American commitment to Article V ('we're going to be with NATO 100 per cent') - but only once he has obtained assurances on burdensharing. ${ }^{90}$

\section{Conclusion}

An administration widely regarded as chaotic led by a president deemed unfit for office hardly seems a good subject for the application of a framework normally seen as premised on actor rationality, bounded or otherwise. ${ }^{91}$ One could go further, Trump's views on NATO and the allies have been coloured by ego, prejudice, sexism, and flattery (Trump seems to have had a particular problem with Germany and Angela Merkel, has blown hot and cold towards French President Emmanuel Macron and, not surprisingly, has warmed to nationalist governments in Poland and Hungary). Yet the calculation Trump has brought to bear on NATO has been straightforward (to get allies to spend more on defence) and so in line with the transactionalist approach that has characterised much of his foreign policy. Here lies the rationality of the Trump approach. But if it is transactional, what does that say, to return to our original question, about the significance of institutions and order? Transactionalism, Robert Zoellick has argued, is dangerous because it is confrontational, sets the interests of one actor against others, and is blind

\footnotetext{
${ }^{88 ‘}$ Remarks by President Trump and Vice President Pence Announcing the Missile Defence Review' (17 January 2019), available at: $\{$ https://www.whitehouse.gov/briefings-statements/remarks-president-trump-vice-president-pence-announcingmissile-defense-review/\}.

${ }^{89}$ See, for instance, 'Trudeau Bills 10-Year Defence Spending Plan as Answer to Trump Spending Call' (12 July 2018), available at: \{https://www.reddeeradvocate.com/news/trudeau-bills-10-year-defence-spending-plan-as-answer-to-trumpspending-call/\}.

${ }^{90}$ Jeremy Herb, 'Trump commits to NATO’s Article V', CNN Politics (9 June 2017), available at: \{https://edition.cnn.com/ 2017/06/09/politics/trump-commits-to-natos-article-5/index.html\}; 'Remarks by President Trump and Vice President Pence'.

${ }^{91}$ Barry, 'Review article', p. 91.
} 
to the benefits of building systems where interests can be negotiated and adjusted. ${ }^{92}$ The administration's approach to NATO, however, modifies that view. Trump has certainly been assertive in the pursuit of American interests. The language in which those interests have been expressed has also been unfailingly blunt. But Trump is also the latest in a long line of American presidents who while complaining at the NATO allies has avoided any form of sanction. The possibility of exit, it is true, has been intimated at, but the actual military commitment to the Alliance has increased. NATO has proven resilient in channelling US demands, in mobilising the US foreign policy and military establishment, and ultimately in being the venue where an outspoken president has been able to exercise voice.

Acknowledgements. A first version of this article was delivered at a roundtable on The Trump Presidency and Global Inequalities convened by Ruth Blakeley at the British International Studies Association annual conference, Brighton, June 2017. The subsequent revised paper benefited significantly from the comments of the journal's anonymous referees and discussions with Mark Webber's colleagues at the University of Birmingham - David Dunn, Patrick Porter, and Adam Quinn.

James Sperling is Professor of Political Science at Akron University. His recent publications include as co-author (with Martin Smith and Mark Webber), NATO's Post-Cold-War Trajectory: Decline or Regeneration? (Palgrave, 2012), as editor, Handbook on Governance and Security (Edward Elgar, 2014), and as co-editor (with Spyros Economides), EU Security Strategies: Extending the EU System of Security Governance (Routledge, 2017).

Mark Webber is Professor of International Politics at the University of Birmingham and Chair (2019-2020) of the British International Studies Association. He is co-author (with James Sperling and Martin Smith) of NATO's Post-Cold-War Trajectory: Decline or Regeneration? (Palgrave, 2012) and co-editor (with Adrian Hyde-Price) of Theorising NATO: New Perspectives on the Transatlantic Alliance (Routledge, 2016). Webber and Sperling are, along with Martin Smith, currently working on a book entitled What's Wrong with NATO and How to Fix It (Polity Press).

\footnotetext{
${ }^{92}$ Robert Zoellick, 'The conflict at the heart of Donald Trump's foreign policy', Financial Times (22 August 2017).
} 